\title{
Effect of Ethanolic Extract of Hyphaen thebaica (L) Seed on Some Haematological, Biochemical and Histological Features of Albino Rats
}

Mohamed K Hassan, Shaimaa M Ali, Ali H Abu-Almaaty and Osama A Abbas

Biotechnology Program, Zoology Department, Faculty of Science, Port Said University, Egypt

*Corresponding author: Hassan MK, Biotechnology Program, Zoology Department, Faculty of Science, Port Said University, Egypt, Tel: +20226831474; E-mail: mohamedkamel24@yahoo.com

Received date: January 16, 2018; Accepted date: February 15, 2018; Published date: February 21, 2018

Copyright: @ 2018 Hassan MK, et al. This is an open-access article distributed under the terms of the Creative Commons Attribution License, which permits unrestricted use, distribution, and reproduction in any medium, provided the original author and source are credited.

\begin{abstract}
It is well known that many diseases throughout the world are well treated with medicinal plants which have great protective and therapeutic effects. The effect of crude ethanolic extract of Hyphaene thebaica (L) Mart (HT) on some hematologicalindices and some biochemical parameters in normal albino rats in addition to the histological studies on liver and kidney tissues of these rats were investigated.

Thirty two normal white male albino rats were divided into four groups of eight rats/each group. Group one served as the control group, group 2, 3 and 4 served as the test groups for the crude ethanolic extract of HT seeds to which oral intubation of $100 \mathrm{mg} / \mathrm{Kg}, 200 \mathrm{mg} / \mathrm{Kg}$ and $400 \mathrm{mg} / \mathrm{Kg}$ dosages of the extracts were administered, respectively. All the rats were fed with normal diet and water ad-libitum for 21 days then after then, all groups were sacrificed, two blood samples were collected for haematological and biochemical parameters. Specimens from liver and kidney were collected for histopathological examination.
\end{abstract}

Group (3; $200 \mathrm{mg} / \mathrm{Kg})$ and group $(4 ; 400 \mathrm{mg} / \mathrm{Kg})$ revealed a significant increase $(P \leq 0.05)$ increase in total WBCs, total RBCs, and haemoglobin concentration compared with the control. However, significant decrease $(P \leq 0.05)$ was observed in the level of cholesterol and triglycerides after treating with $400 \mathrm{mg} / \mathrm{Kg}$ dose only when compared with the control. There was no significant change in platelets count, liver functions (alanine transaminase (ALT), asparatate transaminase (AST), alkaline phosphatase (ALP), gamma-glutamyl transpeptidase (GGT), Albumin and total protein) and kidney functions (urea and creatinine). Histopathological results of taken liver and kidney tissues revealed no significant changes when compared with the control group.

The crude ethanolic extracts of HT seeds hashypolipidimic effect and may be able to boost immune system

Keywords: Seeds; Hyphaene thebaica; Albino rats; Haematological studies; Biochemical studies; liver histopathology

\section{Introduction}

Medicinal plants and their products are the oldest tried health-care products. Their importance is growing not only in developing countries but in many developed countries. Herbal preparations have been utilized to enhance wide range of primary health care delivery due to biochemical content of plant all over the world [1]. All plants parts as roots, seeds, fruits, leaves, flowers stem and bark can all constitute herbal medicines and their values lies in their phytochemical components which produce definite and various physiological actions on human body. Alkaloids, flavonoids and phenolic compounds are considered some of the most important plants' biochemical components [2]. Different diseases as hypertension, diabetes, cough cancer and bacterial infections can be treated by phytochemicals which are extensively present at different level in various medicinal plants [3].

Hyphaene is derived from the Greek word 'hyphaino' (web), referring to the fibers from the leaves, which are used for weaving. The fruit has a brown outer fibrous flesh which is normally chewed. Doum palm kernel is edible when it is unripe but hard when it is ripe
[4].Doum palm seeds have a hard seed coat under the fleshy fibrous pericarp [5].

Hyphaene thebaica (L) Mart (HT) is a desert palm native to Egypt, Sub-Saharan Africa and West India. It is commonly called African doum [6]. It belongs to the family palmae and subfamily Borassoideae [7]. Various extracts of HT (L) Mart are being used in the treatment of bilharzia, haematuria, after childbirth bleeding, and also as ahaematinic agent [8]. The antioxidant activity is shown greatly in the aqueous extract of the plant's fruit because of its luxurious amounts of water soluble phenolic contents [9]. Moreover, its pulp aqueous extract is used in the treatment of diabetes mellitus [10].

The use of Doum, which is rich in saponins, tannins and flavonoids in folk medicine in not surprising [6]. Fruits in specific has nutritional and pharmalogical properties. It was considered scared by the Ancient Egyptians and its seeds were found in many pharaoh's tombs e.g. Tutankhamun's tomb [11]. Research on the fruit pulp of $H$. thebaica showed that it contains nutritional trace minerals, proteins and fatty acids, in particular the nutritionally essential linoleic acid [12]. The identification of compounds, by thin-layer chromatography, showed that the fruit contains significant amounts of saponins, coumarins, hydroxycinnamates, essential oils and flavonoids. The fruit also lowers blood pressure in animal models [13]. In this study we investigated the effect of the crude ethanolic extract of HT seeds on some 
haematological, biochemical and histopathological studies in normal Albino rats. Our results revealed mainly haematological and cellular benefits of the crud extracts from HT seeds.

\section{Materials and Methods}

\section{Plant materials}

The fruits of doum palm (HT) were collected from the local markets to break its fruits and then easily the woody coat of the seeds was removed by light saw. After that the seeds were hit lightly by hammer to break or grind them into very tiny pieces or fine powder as possible to prepare the crude ethanolic extract of these seeds.

\section{Preparation of the ethanolic extract}

HT seeds' ethanolic extract was prepared according to previous study [14]. Twenty gram of powdered plant material was kept in 100 $\mathrm{mL}$ of ethanol in a conical flask. The mouth of the conical flask was covered with aluminum foil and kept in a reciprocating shaker for $24 \mathrm{~h}$ for continuous agitation at $150 \mathrm{rev} / \mathrm{min}$ for thorough mixing and also complete elucidation of active materials to dissolve in ethanol. Then, the extract was filtered by using muslin cloth followed by Whatman (no. 1) filter paper and finally filtered by using vacuum and pressure pump (AP-9925 Auto Science). The solvent from the extract was removed by using rotary vacuum evaporator RE52 with the water bath temperature of $50^{\circ} \mathrm{C}$. Finally, the residues were collected and used for the experiment.

\section{Experimental design}

Thirty two normal white Albino rats weighing (120-150 g) were used for the experiment. The rats were divided into four group's seven rats each. All rats were fed by normal diet and water ad-libitum. Rats in group 1 served as the control, groups 2, 3 and 4 were administered by ethanolic extract daily by intubation for 21 days, with single dose of 100,200 and $400 \mathrm{mg} / \mathrm{kg} \mathrm{B.W.}$, respectively. The rats were kept under normal condition at room temperature during the period of the study. They were then sacrificed by decapitation twenty four hours after the last treatment. Blood samples were collected divided into two portions: The first was taken in EDTA containing tubes from animals of different groups for haematological measurements while the other part was allowed to clot, centrifuged at $3000 \mathrm{~g}$ and serum harvested and used for biochemical analysis. Moreover, parts of liver and kidney tissues were fixed for histopathological investigation.

\section{Haematological and biochemical measurements}

Complete blood count $(\mathrm{CBC})$ includes hemoglobin content, red blood cells (RBC), white blood cells (WBC), and platelets (PT) counts was done by Abbott CELL-DYN1800 automated hematology analyzer, USA, using ready-made kits (Abbott laboratories, Abbott Park, IL, 60064, USA). Serum biochemical analysis was determined by colorimetric methods using ready-made kits (Roche Diagnostics laboratories) using Cobas $^{\oplus}$ analyzer assays include Alanine transaminase (ALT), Aspartate transaminase (AST), $\gamma$ glutamyltransferase (GGT), alkaline phosphatase (ALP), albumin, total protein, urea and creatinine, cholesterol and triglycerides.

\section{Histopathological studies}

The liver and kidney tissues were collected and immediately fixed in $10 \%$ formalin/saline for proper fixation. These tissues were processed and embedded in paraffin wax sections of 4 to 6 microns in thickness. The tissue sections were stained with hematoxylin and eosin (H-E) dye for microscopic examination.

\section{Statistical Analysis}

Data was statistically analyzed using Minitab, using a MINITAB according to previous study [15]. Tabulation and graphics of data were done using Microsoft Excel XP. All of the data of control and treated groups were expressed as mean values \pm standard error. One-way ANOVA and unpaired t-test were carried out to find if there was any significant difference among normal control and ethanolic extracttreated groups at different doses.

\section{Results}

\section{Effect of HT on the haematological parameters}

Studying the haematological parameters revealed that there is a significant $(P \leq 0.05)$ and highly significant $(P \leq 0.01)$ increase in WBCs, RBCs counts in addition to hemoglobin content after oral administration of $200 \mathrm{mg} / \mathrm{Kg}$ and $400 \mathrm{mg} / \mathrm{Kg}$ body weight, respectively, while the dose of $100 \mathrm{mg} / \mathrm{kg}$ body weight didn't induce any appreciated changes when compared with normal control group. Moreover, none of these doses cause any change in the platelets count as shown in Table 1. Comparing the values of the treated groups indicated that 200 and $400 \mathrm{mg} / \mathrm{kg}$ treated groups were significant effective when compared with $100 \mathrm{mg} / \mathrm{kg}$ treated one $(\mathrm{p} \leq 0.05)$ for WBCs and RBCs. $400 \mathrm{mg} / \mathrm{kg}$ treated group showed appreciated $\mathrm{Hb}$ content when compared with $100 \mathrm{mg} / \mathrm{kg}$ treated one (Figure 1).

\begin{tabular}{|c|c|c|c|c|}
\hline Parameter Group & WBCs count $\left(\times 10^{3} / \mu \mathrm{L}\right)$ & RBCs count $\left(\times 10^{6} / \mu \mathrm{L}\right)$ & Hemoglobin (g/dL) & Platelets count $\left(\times 10^{3} / \mu \mathrm{L}\right)$ \\
\hline Negative control group & $11.48 \pm 0.29$ & $7.52 \pm 0.36$ & $13.02 \pm 0.47$ & $581.6 \pm 41.89$ \\
\hline$(100 \mathrm{mg} / \mathrm{Kg})$ of $\mathrm{HT}$ & $11.97 \pm 0.16^{\mathrm{NS}}$ & $7.2 \pm 0.42^{\mathrm{NS}}$ & $13.49 \pm 0.85^{\mathrm{NS}}$ & $585.2 \pm 38.74^{\mathrm{NS}}$ \\
\hline$(200 \mathrm{mg} / \mathrm{Kg})$ of $\mathrm{HT}$ & $12.32 \pm 0.24^{\mathrm{a}^{*}}$ & $8.86 \pm 0.52^{2^{*}}$ & $13.8 \pm 0.90^{a^{*}}$ & $576.4 \pm 21.70^{\mathrm{NS}}$ \\
\hline$(400 \mathrm{mg} / \mathrm{Kg})$ of $\mathrm{HT}$ & $13.20 \pm 0.36^{\mathrm{b}^{\star \star}}$ & $8.859 \pm 0.55^{\mathrm{b}^{* *}}$ & $14.4 \pm 0.82^{\mathrm{b}^{* *}}$ & $587.2 \pm 10.59^{N S}$ \\
\hline
\end{tabular}


Citation: Hassan MK, Ali SM, Abu-Almaaty AH, Abbas OA (2018) Effect of Ethanolic Extract of Hyphaen thebaica (L) Seed on Some Haematological, Biochemical and Histological Features of Albino Rats. J Cytol Histol 9: 494. doi:10.4172/2157-7099.1000494

Page 3 of 7

\begin{abstract}
*,** Results expressed as Mean \pm SE $(n=5)$. ANOVA (P value) represents the difference between all groups. NS Non-significance between normal control group and animals treated with dose of $(100 \mathrm{mg} / \mathrm{kg}, 200 \mathrm{mg} / \mathrm{kg}$ and $400 \mathrm{mg} / \mathrm{kg})$ of HT ethanolic crude extract. aSignificance between normal control group and animals treated with dose of $200 \mathrm{mg} / \mathrm{kg}$ of HT ethanolic crude extract. ${ }^{b}$ Significance between normal control group and animals treated with dose of $400 \mathrm{mg} / \mathrm{kg}$ of HT crude ethanolic extract.
\end{abstract}

Table 1: Effect of oral administration of daily doses of HT seeds' ethanolic crude extract (100, 200 or $400 \mathrm{mg} / \mathrm{Kg}$ BW) after 21 days of treatment on the different haematological parameters of normal male Albino rats.

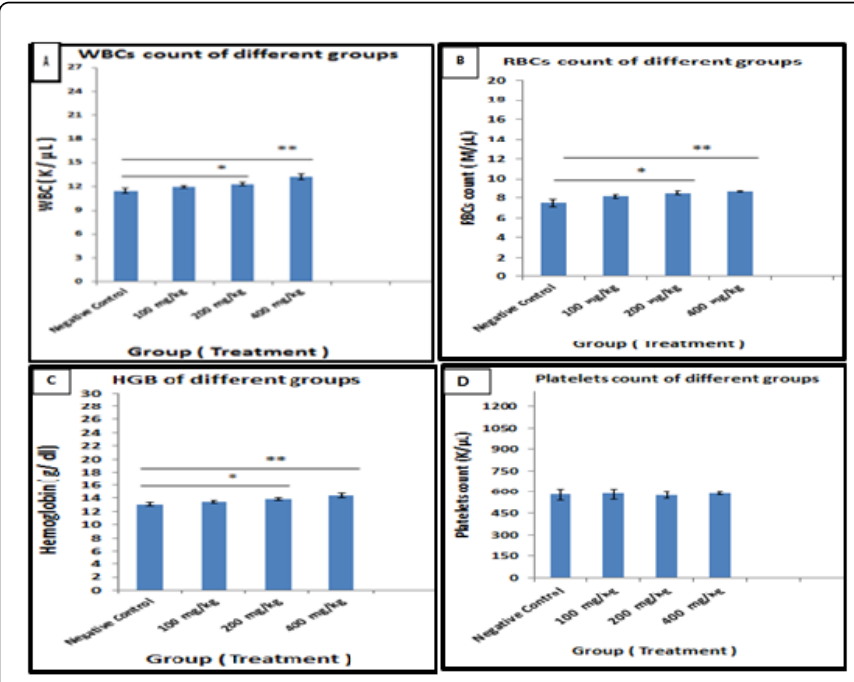

Figure 1: Effect of ethanolic extract of HT seeds oral treatment on alteration of haematological parameters, (A) WBCs count, (B) RBCs count, (C) Hemogolbin content and (D) platelets count ${ }^{\star}(\mathrm{p}<0.05)$.

\section{Effect of HT on the blood biochemistry}

Liver function: We then studied the effect of HT extracts on the liver function. The average levels of serum parameters indicating liver functions are represented in Table 2 and illustrated in Figure 2. These results show that the oral treatment with ethanolic extract of HT seeds at different doses didn't cause significant change.

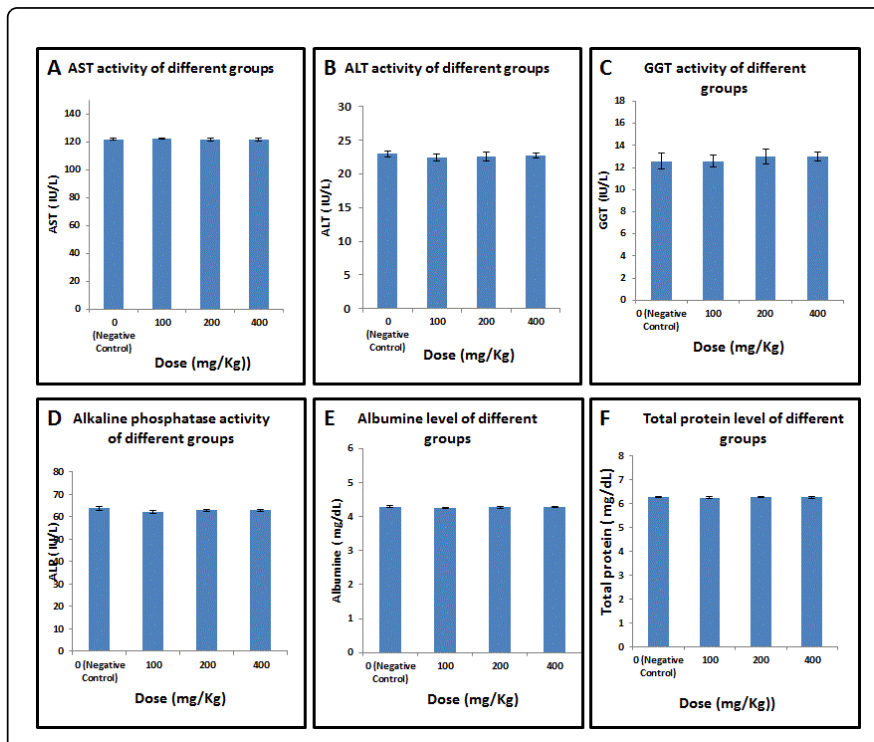

Figure 2: Effect of Ethanlic extract of HT seedsoral treatment on alteration of Liver biochemical parameters, (A) AST activity, (B) ALT activity, (C) GGT activity, (D) ALP activity, (E) Albumine level and (F) Total protein level.

\begin{tabular}{|l|l|l|l|l|l|l|}
\hline Parameter Group & AST (IU/L) & ALT(IU/L) & GGT(IU/L) & ALP(IU/L) & ALB (mg/dl) & TP (mg/dL) \\
\hline Negative control group & $121.8 \pm 0.735$ & $23 \pm 0.447$ & $12.6 \pm 0.678$ & $62.84 \pm 0.420$ & $4.29 \pm 0.03$ & $6.25 \pm 0.03$ \\
\hline$(100 \mathrm{mg} / \mathrm{Kg})$ of HT & $122.4 \pm 0.68^{\mathrm{NS}}$ & $22.4 \pm 0.51^{\mathrm{NS}}$ & $12.6 \pm 0.64^{\mathrm{NS}}$ & $62.3 \pm 0.57^{\mathrm{NS}}$ & $4.26 \pm 0.02^{\mathrm{NS}}$ & $6.24 \pm 0.03^{\mathrm{NS}}$ \\
\hline$(200 \mathrm{mg} / \mathrm{Kg})$ of HT & $121.6 \pm 0.87^{\mathrm{NS}}$ & $22.6 \pm 0.67^{\mathrm{NS}}$ & $13 \pm 0.52^{\mathrm{NS}}$ & $62.9 \pm 0.42^{\mathrm{NS}}$ & $4.27 \pm 0.02^{\mathrm{NS}}$ & $6.27 \pm 0.02^{\mathrm{NS}}$ \\
\hline$(400 \mathrm{mg} / \mathrm{Kg})$ of HT & $121.6 \pm 0.93^{\mathrm{NS}}$ & $22.8 \pm 0.37^{\mathrm{NS}}$ & $13 \pm 0.67^{\mathrm{NS}}$ & $62.88 \pm 0.44^{\mathrm{NS}}$ & $4.27 \pm 0.01^{\mathrm{NS}}$ & $6.25 \pm 0.02^{\mathrm{NS}}$ \\
\hline
\end{tabular}

Results expressed as Mean \pm SE $(n=5)$. ANOVA ( $P$ value) represents the difference between all groups. ${ }^{N S}$ Non-significance between normal control group and animals treated with dose of $(100 \mathrm{mg} / \mathrm{kg}, 200 \mathrm{mg} / \mathrm{kg}$ and $400 \mathrm{mg} / \mathrm{kg}$ ) of HT ethanolic crude extract.

Table 2: Effect of oral administration of daily doses of HT seeds' ethanolic crude extract on of the different serum liver biochemical parameters of normal male Albino rats.

Kidney function: We then decided to study the effect of the extract on the kidney function. The levels in the serum parameters indicating kidney function are represented in Table 3 and illustrated in Figure 3 which show that the oral treatment with ethanolic extract of HT seeds at different doses didn't cause statistically appreciated changes in these parameters.

\begin{tabular}{|l|l|l|}
\hline Parameter Group & Creatinine $(\mathbf{m g} / \mathbf{d L})$ & Urea $(\mathbf{m g} / \mathbf{d L})$ \\
\hline Negative Control group & $0.42 \pm 0.06$ & $14.6 \pm 0.51$ \\
\hline$(100 \mathrm{mg} / \mathrm{Kg})$ of HT & $0.46 \pm 0.05^{\mathrm{NS}}$ & $14.4 \pm 0.51^{\mathrm{NS}}$ \\
\hline$(200 \mathrm{mg} / \mathrm{Kg})$ of HT & $0.46 \pm 0.05^{\mathrm{NS}}$ & $14.2 \pm 0.60^{\mathrm{NS}}$ \\
\hline
\end{tabular}


Citation: Hassan MK, Ali SM, Abu-Almaaty AH, Abbas OA (2018) Effect of Ethanolic Extract of Hyphaen thebaica (L) Seed on Some Haematological, Biochemical and Histological Features of Albino Rats. J Cytol Histol 9: 494. doi:10.4172/2157-7099.1000494

Page 4 of 7

\begin{tabular}{|l|l|l|}
\hline$(400 \mathrm{mg} / \mathrm{Kg})$ of HT & $0.46 \pm 0.05^{\mathrm{NS}}$ & $14.01 \pm 0.51^{\mathrm{NS}}$ \\
\hline
\end{tabular}

Results expressed as Mean $\pm S E(n=5)$. ANOVA ( $P$ value) represents the difference between all groups NSNon-significance between normal control group and animals treated with dose of $(100 \mathrm{mg} / \mathrm{kg}, 200 \mathrm{mg} / \mathrm{kg}$ and $400 \mathrm{mg} / \mathrm{kg})$ of HT ethanolic crude extract.

Table 3: Effect of oral administration of daily doses of HT seeds' ethanolic crude extract $(100,200$ or $400 \mathrm{mg} / \mathrm{Kg} \mathrm{BW})$ after 21 days of treatment on Serum kidney biochemical parameters of normal male Albino rats.
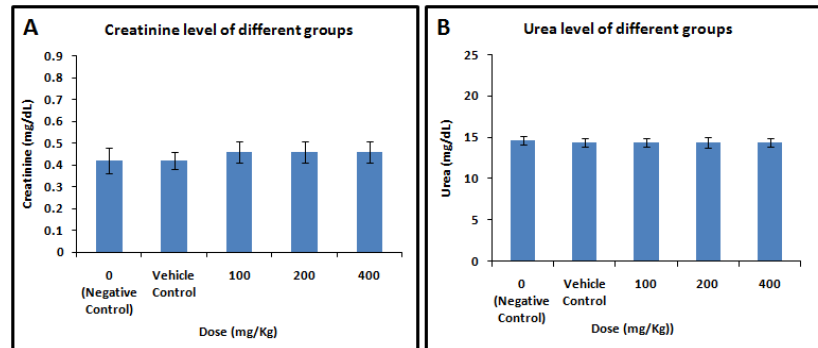

Figure 3: Effect of Ethanlic extract of HT seeds oral treatment on the kidney function parameters, (A) Creatinine level and (B) Urea level.

Blood lipids: Studying the changes in the serum lipids shows that the oral treatment with ethanolic extract of HT seeds at $400 \mathrm{mg} / \mathrm{Kg}$ only, because significant $(\mathrm{p} \leq 0.05)$ decrease in the level of cholesterol but not triglycerides.

\begin{tabular}{|l|l|l|}
\hline Parameter Group & Cholesterol $(\mathbf{m g} / \mathbf{d L})$ & Triglycerides $(\mathbf{m g} / \mathbf{d L})$ \\
\hline Negative Control & $70.1 \pm 4.57$ & $63.84 \pm 0.79$ \\
\hline$(100 \mathrm{mg} / \mathrm{Kg})$ of HT & $74.2 \pm 4.21^{\mathrm{NS}}$ & $65.8 \pm 2.50^{\mathrm{NS}}$ \\
\hline$(200 \mathrm{mg} / \mathrm{Kg})$ of HT & $73.6 \pm 6.17^{\mathrm{NS}}$ & $65.4 \pm 2.48^{\mathrm{NS}}$ \\
\hline$(400 \mathrm{mg} / \mathrm{Kg})$ of HT & $70.2 \pm 3.47^{\mathrm{a}^{*}}$ & $65.6 \pm 2.23^{\mathrm{a}^{*}}$ \\
\hline
\end{tabular}

Results expressed as Mean \pm SE $(n=5)$. ANOVA ( $P$ value) represents the difference between all groups. NSNon-significance between normal control group and animals treated with $100 \mathrm{mg} / \mathrm{kg}, 200 \mathrm{mg} / \mathrm{kg}$ and $400 \mathrm{mg} / \mathrm{kg}$ of HT ethanolic crude extract. aSignificance between normal control group and animals treated with $400 \mathrm{mg} / \mathrm{kg}$ of the extract.

Table 4: Effect of oral administration of daily doses of HT seeds' ethanolic crude extract $(100,200$ or $400 \mathrm{mg} / \mathrm{Kg} \mathrm{BW})$ after 21 days of treatment on Serum lipid biochemical parameters of normal male Albino rats.

But its administration at $100 \mathrm{mg} / \mathrm{kg}$ or $200 \mathrm{mg} / \mathrm{kg}$ body weight didn't cause any change in the same parameters as indicated in Table 4 and illustrated in Figure 4 . Importantly, $400 \mathrm{mg} / \mathrm{kg}$ was statistically effective ( $\mathrm{p} \leq 0.05$ ) when compared with 100 and $200 \mathrm{mg} / \mathrm{kg}$ dose treated one.

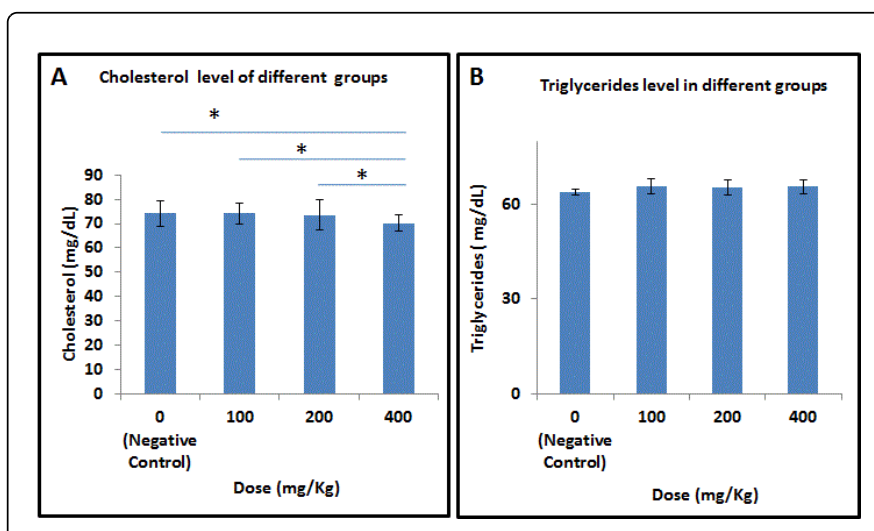

Figure 4: Effect of Ethanolic extract of HT seeds oral treatment on alteration of lipid parameters, (A) cholesterol and (B) triglycerides.

\section{Effect of HT seed extract on the liver histology}

We then decided to assess if the HT extract has any effect on the histological architecture of the liver tissues. Histological study indicated that there are no significant changes in the liver sections between the different groups treated with different concentrations of the HT and control as shown in Figure 5.

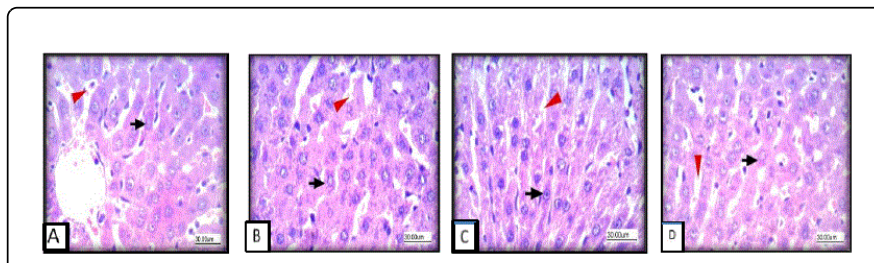

Figure 5: Normal liver formed of hepatocytes black arrow showing abundant esinophilic cytoplasm and small nuclei arranged in thin cell plates of one cell thickness in lobular architecture separated by thin wall blood sinusoids red arrowhead where (A) liver tissue of negative control group, liver tissue of rats treated only with 100 $\mathrm{mg} / \mathrm{Kg}$ BW (B), (200 mg/Kg BW) (C) or (400 mg/Kg BW) (D) of HT seeds' extract.

\section{Effect of HT extract on the kidney histology}

We finally decide to check if there is any effect of HT on the morphology of the kidney tissues. Histological study included the kidney tissues indicated that no of the different concentrations of HT seed extract, used in this experiment, showed significant changes in the kidney tissues as shown in Figure 6. 

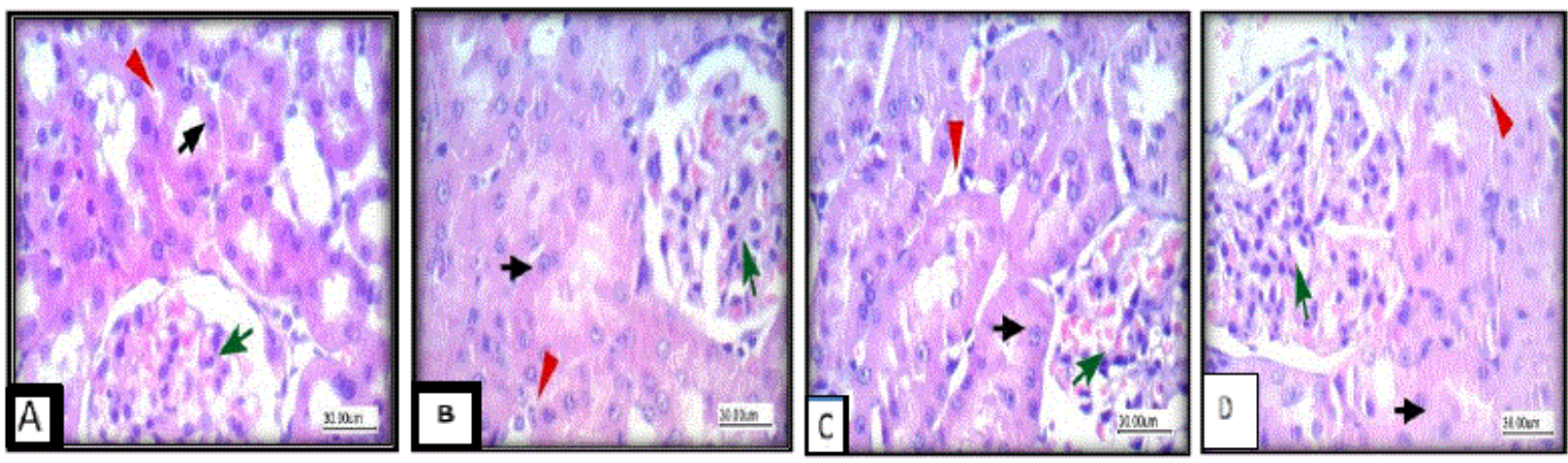

Figure 6: Normal kidney formed of glomeruli and tubules, glomeruli showed capillary tuft green arrow, while tubules lined by columnar cells black arrow with esinophilic cytoplasm and intesrtitium showed blood vessels and stroma red arrowhead. (A) Kidney tissue of negative control group, (B) kidney tissue of rats treated only with (100 mg/Kg BW), (200 mg/Kg BW) (C)or (400 mg/Kg BW) (D) of HT seeds' extract.

\section{Discussion}

Despite increasing medicinal and herbal treatment popularity, its safety and effectiveness remain largely unknown as some of them may cause problems of multiple organ toxicity [16]. It has been reported that substance with lethal dose of $50-500 \mathrm{mg} / \mathrm{kg}$ BW are considered of high toxicity [17]. In this study, as an initial experiment, treating experimental rats with the ethanolic crude extract of HT seeds, at dose of $100-1000 \mathrm{mg} / \mathrm{kg} \mathrm{BW}$, orally, caused no death cases in all the animals which did not help us to conclude the ID50.

Taking into considerations the effect of selected doses of the extract, the current study revealed that HT seeds' ethanolic extract increased WBCs count so it may improve the immunity and helps fight infections. In addition, it caused induction of RBCs count and subsequently increases $\mathrm{Hb}$ concentration. This indicate that the extract may have haematinic effect, particularly, administration of $200 \mathrm{mg} / \mathrm{kg}$ and $400 \mathrm{mg} / \mathrm{kg} \mathrm{B.W}$. of the extract in contrast to $100 \mathrm{mg} / \mathrm{kg} \mathrm{B.W.} \mathrm{dose}$ which didn't show any change in the previous parameters when compared with normal control group. Increased levels of these haematological parameters could be as a result of saponins and flavonoids content of the plant according to the report $[18,19]$. The fact that haemoglobin, RBC and WBC content are increased in HT-treated animals is consistent with the result $[20,21]$ who studied that decoction of doum aqueous stem and bark extracts of HT. These research groups concluded that these extract may induce significant increase in RBCs and $\mathrm{Hb}$ in rats. Moreover, the phagocytic activity of HT could boost immune system and may be useful in the management of anaemia. These results are supported by this of Kamis et al. [12] who reported that the aqueous extract of HT pulp could induce $\mathrm{Hb}$ concentration with a corresponding increase in the red blood cells counts suggesting a haematinic nature of the plant, however the same study did not report significant effect on the white blood cells in contradiction with the results obtained, here, in the present study.

Liver functions of the animals used in this experiment represented by AST, ALT, GGT, ALP, Albumin and total protein while kidney functions represented by serum urea and creatinine levels didn't show appreciated changes upon HT seed's extract administration indicating that this extract did not caused any abnormalities in the metabolic pathways. That was consistent with the findings of Bayed [20] who reported that the long-term treatment of the decoction of doum fruits was safe for animals with no harmful effects on liver and kidney functions owing to its ability to improve serum levels of AST, ALT, ALP, urea and creatinine.

Opposite to our results, a study [22], using ethanolic fruit pulp extract of the plant, reported the hypolipidemic, hepatotoxic and nephrotoxic. However, Modu et al. [23] who used aqueous pulp extract of HT extract reported hypolipidemic but nontoxic effect on both liver and kidney. Another contradicting study [12] reported that rats fed with aqueous pulp suspension of HT mart found to have decrease in the levels of total proteins and albumin which suggested impairment in the normal liver function according to Debruin [24].

Hyperlipidemia, is a medical condition characterized by an increase in one or more of the plasma lipids, including triglycerides, cholesterol, cholesterol esters, phospholipids and plasma lipoproteins including very low-density lipoprotein and low-density lipoprotein along with reduced high-density lipoprotein levels. The elevation of plasma lipids is among the leading risk factors associated with cardiovascular diseases [25], including atherosclerosis. Our study showed that animals which received crude ethanolic extract of HT seeds at $(400 \mathrm{mg} / \mathrm{Kg}$ BW) caused a significant decrease $(\mathrm{p} \leq 0.05)$ in levels of cholesterol and triglycerides concentration in the blood proving its hypolipidemic properties and these results were consistent with those previously $[20,21,26]$.

The antioxidant activity of Doum plant is due to the substantial amounts of water-soluble phenolic contents of flavonoids [27]. So, in a study [26] that team observed that presence of flavonoids or phenolic compounds which act as antioxidants in the Doum fruit extractions can prevent LDL and membrane fatty acids from lipoperoxidation and this could be an effective tool in the prevention of atherosclerosis [28]. Our findings is also consistent with those [29] who used other part of the HT fruit and reported a beneficial dietary hypotensive, hypolipidaemic and a significant decrease in systolic blood pressure, diastolic blood pressure, total cholesterol, triglyceride and LDL-C in treated patients compared to non-treated ones, while they reported an increase of the HDL-C.

The efficiency of many plants as medicinal resources is due to the presence of flavonoids (polyphenols) and saponins, for example, grape, hence the use of Doum, which is rich in flavonoids and saponins, in folk medicine is not surprising [6]. Oral administration of 
phenonol-containing extracts has inhibited platelet function [30], and reduces thrombus formation [30]. At the vascular wall, polyphenols exert vasorelaxant effects [31] inhibit the adhesion of monocytes to the endothelium [32,33], and improved endothelial function [34]. Polyphenols have also been shown to reduce the development of atherosclerosis in animal models [35]. This supports our finding that the histological investigation in this study offered more evidence that HT seed extract keeps the same features of normal liver and kidney tissues after administration.

\section{Conclusion}

According to the results HT seed extract seems to have hypolipedimic and hematinic effect in the experimental animals. The extract significantly enhanced the both WBCs and RBCs and relatively increases $\mathrm{Hb}$ content. However, HT extract did not affect the liver or kidney functions or their tissues architectures.

\section{References}

1. Elujoba AA, Odeleye OM, Ogunyemi CM (2005) Traditional medicine development for medicinal and dental health care delivery system in Africa. African Journal of Traditional, Complementary and Alternative Medicine 2: 46-61.

2. Shariff ZU (2001) Modern herbal therapy for common ailment. Nature pharmacy series, pp: 9-84.

3. Carlo G, Autore G, Izzo AA, Maichino P, Mascola N (1993) Inhibition of intestinal motility and secretion of flavonoids in mice and rats: structure activity relationship. Journal of Pharmacology and Pharmaceuticals 45: 1054-1059.

4. Moussa H, Hank A, Margolis HA, Dube P, Odongo J (1998) Factors Affecting the Germination of Doum Palm (Hyphaene thebaica Mart.) Seeds from the Semi-Arid Zone of Niger, West Africa. Forest Ecology and Management 104: 27-41.

5. Mohammed AA, Yusef SS (2008) Seed Scarification Requirement in Doum (Hyphaene thebaica Mart.). Scientific Journal of King Faisal University (Basic and Applied Sciences) 9: 75-84.

6. Dosumu OO, Nwosu FO, Nwajo CJ (2006) Photochemical screen in gand antimicrobial studies of extracts of Hyphaene thebaica (L) Mart Palmae. International Journal of Tropical Medicine 1: 186-189.

7. Amin ES, Paleologou AM (1973) Biochemical studies on Hyphaenethebaica (L) Mart fruit carbohydrate research 272: 447-450.

8. Adaya AL, Bdliya H, Bitrus H, Fanjaji M, Eaton D, et al. (1977) Hidden Harvest project. Research series, Complied by International institute for environmental and Development and National Nutrition Certification Program 3: 14-27.

9. Hsu B, Conpa IM , Ng K(2006) Antioxidant activity of hot water extract from the fruit of the doum palm, Hyphaene thebaica. Food chemistry 98: 317-328.

10. Shehu BB, Gidado A, Buratai LB (2014) Hypoglycaemic effect of extract of Hyphaenethebaica (L) Mart fruit pulp in normal and alloxan induced diabetic rats. Journal of Applied Bioscience 6: 6-15.

11. Hetta MH, Yassin NZ, El Shaer MA (2005) Effect of Hyphaenethebaica on the spermatogenesis of male rats. Egypt Med J NRC 4: 35-39.

12. Kamis AB, Modu S, Zanna H, Oniyangi TA (2003) Preliminary biochemical and haematological effects of aqueous suspention of pulp of Hyphaenethebaica (L.) mart in rats. Biokemistri 13: 1-7.

13. Sharaf A, Sour A, Gomaa N, Youssef M (1972) Some Pharmacological Studies on Hyphaene thebaica Mart Fruits. Qualities Planetarium Matriae Vegetable 22: 83-90.

14. Nagappan (2012) Evaluation of aqueous and ethanol extract of bioactive medicinal plant, Cassia didymobotrya (Fresenius) Irwin and Barneby against immature stages of filarial vector, Culexquinquefasciatus Say
(Diptera: Culicidae). Asian Pacific Journal of Tropical Biomedicine 2: 707-711.

15. Lenth RV (1989) Quick and easy analysis of unreplicated factorials. Technometrics, 31: p. 469.

16. Udem S, Obidike R, Onyejekwe O (2012) Preliminary investigation into the acuteand chronic ingestion of aqueous leaf extract of Swieteniamahagoni (Maliceae) in rats. Journal of Comparative Clinical Pathology 21: 813-818.

17. Clarke EG, Clarke ML (1977) Veterinary Toxicology. Bailliere Trindall, London 55-75.

18. Sumanti A, Kapoor W (1986) Influence of dietary iron on blood and haemoglobin concentration. Dietetics 23: 257-261.

19. Auwal MS, Sanda KA, Mairiga IA, Lawan FA, Mutah AA, et al. (2013) The phytochemical, elemental and haematologic evaluations of crude mesocarp extract Hyphaenethebaica (Doum Palm) on Wistar Albino Rats. Asian Journal of Biochemistry 8: 14-23.

20. Bayad AE (2016) Influences of doum fruit (Hyphaenethebaica) extract on the reproductive parameters, blood picture, lipid profile and hepato-renal functions in rats. Merit Research Journal of Medicine and Medical Sciences 4: 384-391.

21. Shehu BB, Bislava SB, Gadaka MA, Tukur MA (2015) Effect of aqueous stem and bark extracts of Hyphaene thebaica (L) mart on some hematological parameters in normal wister strain albino rats. Kanem Journal of Medical Sciences 9: 1-7.

22. Kamis AB, Modu S, Markus PY (2000) Some biochemical effects of various doses of ethanolic pulp extract of Hyphaene thebaica. Nigerian Journal of Experimental and Applied Biology 1: 33-36.

23. Modu S, Kamis AB, Markus PY (2000) Some biochemical effects on aqueous pulp extract of Hyphaene thebaica (L) Mart determination in rats. Journal of life and environmental sciences 2: 139-143.

24. Debruin A (1976) Biochemical function test. In Biochemical toxicology of Environmental Agents 8: 451- 470.

25. Shattat GF (2014) A Review Article on Hyperlipidemia: Types, Treatments and New Drug Targets. Biomedical and Pharmacology Journal 7: 399-409.

26. Hetta MH,Yassin NZ (2006) Comparative studies on hypocholesterolemic effect of different fractions of Hyphaene thebaica (Doum) in experimental animals. Die Pharmazie-An International Journal of Pharmaceutical Sciences 61: 230-232.

27. AbdEl-Moniem M, Mustafa HN, Megahed HA, Agaibyi MH, Hegazy GA, et al. (2015) The ameliorative potential of Hyphaene thebaica on streptozotocin-induced diabetic nephropathy. Folia Morphlogica 74: 447-457.

28. Remesy C, Manach C,Demigne C, Texier O, Regerat F (1996) Nutritional interest of flavonoids. Medecineet Nutrition 32: 17-27.

29. El-Gendy A, El-Mileegy A, Ghyaty E, Malek HA, Mousa AEH (2008) The beneficial dietary hypotensive and hypolipidaemic effects of Hyphaene thebaica (Doum). Internet Journal of Alternative Medicine 7: 45-51.

30. Demrow HS, SlanePR, Folts JD (1995) Administration of wine and grape juice inhibits in vivo platelet activity and thrombosis in stenosed canine coronary arteries. Circulation 91: 1182-1188.

31. Zenebe W, Pechanova O, Andriantsitohaina R (2003) Red wine polyphenols induce vasorelaxation by increased nitric oxide bioactivity. Physiological Research 52: 425-432.

32. Carluccio MA, Siculella L, Ancora MA (2003) Olive oil and red wine antioxidant polyphenols inhibit endothelial activation: antiatherogenic properties of Mediterranean diet phytochemicals. Arteriosclerosis, Thrombsis, and Vascular Biology 23: 622-629.

33. Badia E, Sacanella E, Fernandez-Sola J (2004) Decreased tumor necrosis factor-induced adhesion of human monocytes to endothelial cells after moderate alcohol consumption. The American Journal of Clinical Nutrition 80: 225-230.

34. Stein JH, Keevil JG, Wiebe DA, Aeschlimann S (1999) Purple grape juice improves endothelial function and reduces the susceptibility of LDL 
Citation: Hassan MK, Ali SM, Abu-Almaaty AH, Abbas OA (2018) Effect of Ethanolic Extract of Hyphaen thebaica (L) Seed on Some Haematological, Biochemical and Histological Features of Albino Rats. J Cytol Histol 9: 494. doi:10.4172/2157-7099.1000494

Page 7 of 7

cholesterol to oxidation in patients with coronary artery disease. Circulation 100: 1050-1055.

35. Stocker R, O'Halloran RA (2004) Dealcoholized red wine decreases atherosclerosis in apolipoprotein E gene-deficient mice independently of inhibition of lipid peroxidation in the artery wall. American Journal of Clinical Nutrition 79: 123-130. 